\title{
Teachers' Perceptions of Using Technology in Teaching EFL
}

\author{
Fatemeh Mollaei \\ Islamic Azad University, Shiraz Branch, Shiraz, Iran \\ Mohammad Javad Riasati \\ Department of Foreign Languages, Shiraz Branch, Islamic Azad University, Shiraz, Iran \\ E-mail: mjriasati2002@yahoo.com
}

Received: 14-08- 2012

Accepted: 11-09- 2012

Published: 01-01- 2013

doi:10.7575/ijalel.v.2n.1p.13

URL: http://dx.doi.org/10.7575/ijalel.v.2n.1p.13

\begin{abstract}
No longer are students' experiences with new languages limited to their textbooks or immediate environment. With the pervasiveness of the internet and the increased awareness of the importance of having technology in a classroom, both teachers and students all over the world are being provided with technological tools that will further accelerate their ability to acquire or teach a second or foreign language. Technology integration in the classroom has become an important aspect of successful teaching. It has triggered many researchers to investigate different aspects of such integration. In addition, it could be an effective teaching tool when used to engage all students in the learning process. The results of the study show that teachers have positive attitudes toward the use of technology, particularly computer. The focal point of the project was to promote students' communicative competence and autonomy via the implementation of technological tools. This study aimed at investigating the perceptions of EFL teachers about the use of technology in their classes and factors affecting technology implementation in Iranian Language Institutes. Descriptive statistics and sample t-test were used to analyze the questionnaire data. Results obtained from both the quantitative and qualitative data revealed teachers' perceptions about integrating technology in their classes, incentives for teachers who use technology, types of technology used, facilitating and inhibiting factors affecting technology implementation, and the different attitudes of male and female teachers toward using technology. According to the results, teachers had positive attitudes regarding the use of technology, in particular computer, in their classrooms.
\end{abstract}

Keywords: Technology, computer, EFL teachers

\section{Introduction}

In recent years, the rapid evolution of information and communication technology (ICT) has made great changes in societies and education. Technology not only gives learners the opportunity to control their own learning process, but also provides them with ready access to a vast amount of information over which the teacher has no power or control (Lam \& Lawrence, 2002).

According to Atkins and Vasu (2000), teachers' attitudes or concerns have a significant influence on the use of computers in the classroom. Lam (2000) also emphasizes that teachers' personal beliefs of the advantages of using technology for language teaching influence teachers' decision regarding technology use. Similarly, Kim (2002) points out that critical factors affecting successful integration of technology into the classroom are associated with teachers themselves, such as teachers' perceptions and attitudes. She adds that teachers' perceptions and attitudes toward teaching and technology can be regarded as a facilitating or inhibiting factor, giving them more confidence or a major barrier of technology use. Redmond, Albion and Maroulis (2005) also reported that teachers' personal backgrounds such as personal confidence, interests in using ICT and willingness to try something different are significant factors that might promote ICT integration in the classroom. However, Egbert, Paulus and Nakamichi (2002) assert that a positive attitude toward computer technology does not guarantee that teachers will be able to use the technology in the classroom. Kim (2002) found that teachers' actual use of Web-based lessons was limited, frequently delayed, avoided or withdrawn. They encountered some unexpected difficulties or barriers due to lack of sufficient knowledge and computer skills, lack of experience, insufficient time, computer anxiety and lack of confidence, although all participants in her study had positive attitudes toward the use of technology and strong intrinsic motivation such as personal curiosity and interest. The most common reasons for not using computers included limited class hours, inconvenience of using computer facilities and technical problems such as slow Internet connections. In addition, they had problems related to integrating authentic materials into their textbooks. Learners are expected to be active participants in the learning process rather than passive recipients since they control their own learning in a technology-enhanced learning environment (Brown, 1991).

Teachers encounter new demands of those learners in integrating new technologies into the second/foreign language classroom. They also look for better ways of providing students with linguistic skills, meaningful communication and culture. In the technology-enhanced environment, learners could manage their own learning process by gathering information and negotiating meaning themselves. The classroom became more learner-centered, that is, learners were 
able to make their decisions and became responsible for their work more independently. The teacher, on the other hand, became a "facilitator, a resource person and a counselor rather than the only authority and decision-maker" (p. 305). Bancheri (2006) asserts that teachers' role in the new era of technology is not only to transmit new knowledge, but to give students tools to acquire knowledge and recognize the value of what they see in books and software as well as on the Internet. In addition, Jeong (2006) emphasizes that the role of teachers in EFL settings is more crucial than ever before because teachers are able to motivate students and try to create language learning environments which are nonthreatening, meaningful and affectively supportive by using Web technology. If language teachers have a variety of positive teaching and learning experiences in using computers, they are likely to be more confident and skillful in implementing CALL (Computer-Assisted Language Learning) in their own classrooms. Therefore, teacher development programs should be provided for language teachers to deal with issues of using computers (Jung, 2001; Lee \& Son, 2006; Son, 2002, 2004; Suh, 2004) and gain competent skills in managing computer-based tasks and activities in the classroom (Johnson, 2002; Oh \& French, 2007). As CALL can be enriched by teachers, teachers' views on CALL implementation are crucial. Considering that CALL activities should be integrated into the existing curriculum according to learners' levels of language and computer literacy, teachers need to explore the full potential of CALL programs and utilize them creatively in the classroom.

The research questions of the present study are as the followings:

1. How do experienced teachers perceive learning through technology?

2. How do teachers view the use of technology in enhancing language teaching and learning?

3. Can computer-oriented technology contribute to students' language learning?

4. Is there any difference in using technology by male and female teachers?

5. What is teachers' attitude toward technology implementation in EFL classes?

\section{Review of Related Studies}

Research into the impact of learning technologies on the quality of students' learning outcomes is limited and outdated according to Honey, Culp and Carrigg (2000). A limiting factor has been the difficulty of defining and measuring enhanced learning outcomes attributable specifically to the use of learning technologies (Mitchell \& Bluer, 1997). Recent research has avoided this difficulty and focused on investigating the requirements for successful integration of learning technologies into classrooms. The research is beginning to show that success requires understanding the complex interactions in classrooms between teachers, students and technology (Honey, Culp \& Carrigg, 2000). This understanding is currently incomplete. Parr (1999) studied students' perceptions of learning contexts that incorporated learning technologies. Students' perceptions were found to influence the success of integration, specifically the amount of technology use, the ways in which the technology was used, and teachers' and students' expectations about learning. Teachers' perceptions of learning technologies and influence on students' perceptions have not been studied recently. To further understanding, our study investigated experienced teachers' perceptions of learning technologies. The research also considered the likely impact of teachers' perceptions on students' perceptions and, consequently, on the integration of learning technologies into classrooms.

The research into teachers' and students' perceptions of teaching and learning contexts established a series of systematic associations linking teachers' perceptions and approaches with students' perceptions, learning approaches and outcomes (Biggs, 1999; Marton \& Booth, 1997; Prosser \& Trigwell, 1999). An explanation of these associations is important to understand the significance of investigating teachers' perceptions of learning technologies.

Teachers conceptualize and approach teaching in a limited number of qualitatively different but related ways. Broadly, teachers who perceive learning as the accumulation of information are more likely to view teaching as the transfer of information. Such teachers are more likely to use a teacher-centered approach where the teacher imparts information to students and uses assessment techniques which encourage and test rote learning. In contrast, teachers who view learning as conceptual change are more likely to view teaching as facilitating conceptual change. Such teachers are more likely to use a student-centered teaching approach where independence in learning is encouraged through discussion, debate and questioning among students, and assessment which reveals conceptual change (Prosser \& Trigwell, 1999).

Students' approaches to learning are related to their teachers' approaches to teaching (Trigwell, Prosser \& Waterhouse, 1999). Teachers who describe using a conceptual change/student focused teaching approach are more likely to be teaching students who report using a deep approach to learning. Deep learning approaches have an intention to seek meaning in learning situations through linking aspects of the content. With a deep learning approach there is the possibility of the conceptual change and deeper understanding which is assumed in this paper to constitute an enhanced learning outcome (Cope, 2000; Marton \& Booth, 1997). Indeed, in many empirical studies deep learning approaches have been found to be strongly associated with conceptual change learning outcomes (e.g., Marton \& Säljö, 1976; Prosser \& Millar, 1989). In contrast, teachers who describe using an information transfer/teacher-centered teaching approach are more likely to be teaching students who report using surface learning approaches. Surface learning approaches focus on memorizing aspects of the content in isolation with the intention of recalling the content in assessment situations. There is little intention to seek meaning in the content, and little likelihood of significant conceptual change (Ramsden, 1988).

An explanation of the association between teacher and student approaches has been proposed and supported empirically by Prosser \& Trigwell (1999). The learning context provided by a teacher is the practical implementation of the teacher's perceptions of learning and teaching, and approach to teaching. Students have been found to vary their 
learning approach in response to certain factors they perceive in the learning context. Students using deep learning approaches are more likely to value independence in learning, good teaching and clear learning goals, factors consistent with a student-centered teaching approach. Students using surface learning approaches are more likely to have different values, and, consequently different perceptions.

So how do teachers perceive learning technologies? In the past decade, the nature of learning technologies has changed, with text-based, locally-networked, computer-assisted instructional software being replaced by graphics-rich, globallynetworked computer environments, which makes earlier studies less helpful (Honey, Culp \& Carrigg, 2000). Professional development programs have been targeted at keeping experienced teachers' knowledge current. Research indicates, however, that brief-exposure programs about technology made available to experienced teachers have been unsuccessful.

Liu, Theodore and Lavelle (2004) insist that teachers' attitudes or concerns about technology can influence successful technology integration. This is in line with the argument put forward by Atkins and Vasu (2000), who argued that teachers' technology use and knowledge are significantly related to their confidence level. Similarly, Lam (2000) notes that teacher confidence is influential because a lack of confidence can hinder teachers' use of technology in the classroom. Rakes and Casey (2000) also stated that teachers must be comfortable with technology and have positive attitudes toward technology integration to improve students' achievement. They added that teachers' concerns on technology use need to be considered because they affect teachers' behavior. This implies that teachers' personal comfort with technology is essential for the successful integration of technology. Several researchers (e.g., Egbert, Paulus \& Nakamichi, 2002; Lam, 2000; Oh \& French, 2007; Yildirim, 2000) found that, as a result of teacher training programs, teachers improved their capabilities with computers, gained confidence with technology and expressed the view that teacher development programs influenced their attitudes toward technology positively. Egbert, Paulus and Nakamichi (2002) discovered that teachers who had previous experience with technology use were more likely to use CALL activities in the classroom. They added that peers and colleagues are the most common resource of finding out about new CALL activities. The results of their study indicate that teachers are likely to learn best by observing fellow teachers' class and teaching methods used in actual classrooms, trying out new techniques, getting feedback on their teaching and talking to colleagues and fellow teachers. With similar views of teacher education, Jung (2001) claims that school-based, workshop style technology training programs should be introduced, where well-trained colleagues help less skillful teachers use technology in their classrooms and tutor each other on a one-on-one basis. Interestingly, a study conducted by Bax (2003) indicates that many people have excessive beliefs on computer technology in language learning. In other words, they tend to think that CALL should do everything and replace current teaching tools such as dictionaries and even the teacher. This leads to a misguided assumption that the mere existence of computer technology in classes was the only relevant factor in achieving successful implementation of CALL, while all other crucial factors such as teacher training, pedagogical support and ways of CALL integration had been neglected. To avoid the mistaken idea, which is an obstacle influencing the implementation of CALL (Bax, 2003), it is important to note that CALL practitioners should take into account various elements, including teachers' perspectives of and attitudes toward the use of technology, for achieving the successful implementation of CALL.

A number of studies (e.g., Atkins \& Vasu, 2000; Egbert, Paulus \& Nakamichi, 2002; Jung, 2001; Kim, 2002; Lam, 2000; Lee \& Son, 2006; Shin \& Son, 2007; Suh, 2004; Yildirim, 2000) indicate that factors such as teacher training and computer facilities, teachers' attitudes toward computers and prior teaching experiences with ICT are strongly related to the success or failure of CALL in the classroom. They also point out external or environmental factors (e.g., financial problems, strict curriculum) and teacher-related factors (e.g., pedagogical, affective or other personal attitudes and beliefs). Specifically, financial problems, insufficient materials and time, lack of technical support and inflexibility of curriculum are mentioned as common external barriers affecting CALL practices. A report on American public teachers' use of technology (Smerdon, Cronen, Lanahan, Anderson, Iannotti \& Angeles, 2000) also reveals that insufficient numbers of computers and lack of time for teachers to learn how to use computers or the Internet are great barriers to their use of computers for instruction.

Atkins and Vasu (2000) regard teachers as one of the most important factors influencing technology use and argue that teachers' attitudes or concerns have a significant impact on the integration of the computer into the classroom. Kim (2002) also agrees that a teacher as an individual with complex internal variables is a key element affecting the use of the computer in the classroom. These studies suggest that teachers who have basic computer competencies are more confident in using computers and are more likely to integrate computers into their teaching than those who have not.

\section{Methodology}

\subsection{Participants}

A total number of 40 undergraduate and graduate EFL teachers participated in the study. All teachers were working in English language institutes in Shiraz, Iran. Of the forty participants, 20 were male teachers and 20 were female teachers. Their teaching experience ranged between 4 to 10 years. Furthermore, seven participants were asked to take part in the interview.

\section{2 Instrumentation}

As using quantitative data collection methodology does not always give a true picture of technology integration in EFL classrooms, we decided to use a mixed-methodology. First, a 30-item questionnaire, designed to elicit teachers' perceptions of the use of technology in language classrooms, was distributed among the teachers. They were asked to rate statements based on their level of agreement or disagreement to indicate their perceptions and attitudes toward technology 
implementation. Cronbach alpha was used to determine the reliability of questionnaire and it was 0.81 . The questionnaire was on a five-point Likert scale ranging from 5 (strongly agree) to 1 (strongly disagree).

Later, focus group interviews were conducted with seven teachers. Each interview lasted for around 15 minutes. Qualitative methodology aimed at eliciting information about male and female teachers' perspectives on technology implementation, in particular computer in their own teaching contexts. During the interviews, the following questions were asked:

1. What do you think of using technology in teaching of EFL?

2. What types of technologies do you prefer to use in your classroom?

3. What types of technologies you think appropriate for using in EFL classes (especially in our country)?

4. What are the benefits to teacher's uses of technology in EFL classes?

5. What are barriers to teacher's uses of technology in EFL classes?

6. What factors do you think affect your use of technology, especially computer?

\subsection{Data Analysis}

The data obtained from the questionnaires were subjected to SPSS. First, descriptive statistics were run. Then, t-test was administered in order to determine the probable differences between male and female teachers' responses. The interview data were also analyzed to see how they supplement the quantitative data.

\section{Results and Discussion}

\subsection{Data from questionnaires}

The following section presents the findings emerging from the questionnaires according to the research questions. Sample t-test was used to compare the mean between male and female teachers' perception toward technology integration in their classes with intervening mean (3).

To answer the first research question as "How do experienced teachers perceive learning through technology?" the statements mentioned in Table 1 were provided to both groups of participants. Results indicated that the mean among male and female teachers was higher than mean (3) and it was significant at the level of significance equal to 0.001 $(\mathrm{P}<0.001)$. Thus, teachers had higher perceptions toward technology integration in their classes. (see Table 1.1). This meant that most teachers were willing to use technology in their classes and used it more creatively. The highest mean scores were obtained for items related to acquiring language, students' interactions, academic achievement and grades improvement, making language learning interesting, students' motivation increases, and activating learning during language classes.

Table 1. Mean and Standard Deviation of Teachers' Perceptions toward Technology Integration

\begin{tabular}{lcc}
\hline \multicolumn{1}{c}{ Variables } & Mean & SD \\
\hline Using technology helps students acquire languages. & 4.53 & 0.60 \\
Students can interact and communicate differently with the help of technology. & 4.15 & 0.48 \\
Technology assists students in improving academic achievement and grades. & 4.25 & 0.54 \\
Technology assists in making language learning interesting and enjoyable. & 4.64 & 0.57 \\
Students' motivation increases as a result of using technology in teaching. & 4.22 & 0.73 \\
Technology assists in activating learning during language classes. & 4.15 & 0.62 \\
\hline
\end{tabular}

Table 1.1. Teachers' Perceptions toward Technology Integration

\begin{tabular}{cccccc}
\hline $\mathrm{N}$ & $\mathrm{M}$ & $\mathrm{SD}$ & $\mathrm{t}$ & $\mathrm{df}$ & $\mathrm{P}$ \\
\hline 40 & 4.32 & 0.37 & 22.43 & 39 & 0.001 \\
\hline
\end{tabular}

Regarding the response of the second question "How do teachers view the use of technology in enhancing language teaching and learning?", the statements mentioned in table 2 were given to the participant. According to the results the mean of female and male teachers' views of using technology in enhancing EFL learning was higher than mean (3) and it was significant at the level of significance $0.001(\mathrm{P}<0.001)$. Hence, both groups had positive attitudes toward using technology to enhance language and teaching learning. (Table 2.1)

A similar conclusion was made by Yang \& Huang (2008) who found that teachers used technology mainly to prepare their teaching activities and did not pay much attention to the utilization of technology in promoting crucial instructional activities. ChanLin, et al. (2006), however, argued that teachers used technology to prepare tests, activities and handouts because they wanted their teaching to be diverse and creative. They also argued that a computer might be employed as a self-monitoring instrument to encourage students to make more creative efforts. 
Table 2. Mean and Standard Deviation of Teachers' Views of Using Technology in Enhancing EFL Learning

\begin{tabular}{lcc}
\hline \multicolumn{1}{c}{ Variables } & Mean & SD \\
\hline Technology helps students improve their language skills and knowledge. & 4.22 & 0.73 \\
Technology helps in integrating different language activities. & 4.08 & 0.92 \\
Technology helps students meet different needs in the classroom. & 3.78 & 0.80 \\
Technology assists in abandoning the traditional approaches and developing more & 4 & 0.99 \\
interactive ways in teaching and learning languages. & 4 & 0.85 \\
Technology plays a great role in learning the different language skills. & 4.33 & 0.73 \\
Technology provides students with tools for using electronic pronunciation dictionaries. & 3.75 & 0.71 \\
Technology helps students understand academic subjects better. & 4 & 0.75 \\
Technology assists in developing electronic exams and making them in the same way. & 3.45 & 1.13 \\
Students become more independent learners as a result of technology. & 4.03 & 1.05 \\
Using technology in the classroom has many benefits to teachers and students alike. & \\
\hline
\end{tabular}

Table 2.1. Teachers' views of using technology in enhancing EFL learning

\begin{tabular}{cccccc}
\hline $\mathrm{N}$ & $\mathrm{M}$ & $\mathrm{SD}$ & $\mathrm{t}$ & $\mathrm{df}$ & $\mathrm{P}$ \\
\hline 40 & 3.96 & 0.45 & 13.46 & 39 & 0.001 \\
\hline
\end{tabular}

In order to answer question 3 "Can computer-oriented technology contribute to students' language learning?", the statements mentioned in Table 3 were presented to the participants. Results showed that both groups agreed on using computer-oriented technology as it contributes to students' learning. Obviously, the mean of computer-oriented technology contribution to language learning variable between both groups was higher than mean (3) and it was significant at the level of significance $0.001(\mathrm{P}<0.001)$. Therefore, teachers had a positive attitude toward computeroriented technology in language learning. (Table 3.1.)

Computers have changed the way that many teachers approach teaching. Teachers are now able to use computers to demonstrate dynamic processes in real time such as providing students with simulations of how gases behave at different temperatures in science classes (Hurwitz, 1999) or showing videos and movie clips of significant historical events, all of which allow the teacher to provoke deeper thought processes. Several older digital natives who have used computers, both in and out of the classroom, over the past two decades would recognize, as well as welcome, the necessity for an informal and critical approach to the use of computers in education (Loveless, 1999). Despite the enormous headway that computer technology has made, there is still a common misconception that computers and the Internet are the only useful technologies for the field of education (Lyle, 2009). However, education technology is actually spread throughout a broad spectrum of different technologies including, but not limited to, those used in "design, making, problem-solving, technological systems, resources and materials, criteria and constraints, processes, controls, optimization and trade-offs, invention, and many other aspects dealing with human innovation" (Lyle, 2009, $35)$.

Table 3. Mean and Standard Deviation of Computer-Oriented Technology Contribution to Language Learning

\begin{tabular}{llc}
\hline \multicolumn{1}{c}{ Variables } & Mean & SD \\
\hline $\begin{array}{l}\text { Computer technologies provide non-native speakers of English rich learning } \\
\text { environment. They can practice the activities as many times as they wish. }\end{array}$ & 4.35 & 0.66 \\
\hline $\begin{array}{l}\text { Teacher's role is quite different in a computer-oriented learning environment } \\
\text { compared to traditional teacher-centered lesson. }\end{array}$ & 3.80 & 1.14 \\
\hline $\begin{array}{l}\text { Students' attention is distracted by digitized sound and they don't concentrate on } \\
\text { studying. }\end{array}$ & 2.53 & 0.99 \\
\hline Students are more engaged in learning due to technology. & 3.95 & 0.90 \\
\hline $\begin{array}{l}\text { The interaction between students and the computer is one-sided, so the students just } \\
\text { watch and listen to the sounds. }\end{array}$ & 2.85 & 0.95 \\
\hline $\begin{array}{l}\text { Many students complain about the tiredness of their eyes and necks after using } \\
\text { computer. }\end{array}$ & 3.45 \\
\hline $\begin{array}{l}\text { Teachers' excessive dependence on the computer technology may result in } \\
\text { insufficient preparation of teaching materials. }\end{array}$ & 2.98 \\
\hline The computer facilities in my school are very old and not in good condition. & 0.93 \\
\hline Insufficient facilities discourage teachers from using technology. & 3.90 \\
\hline $\begin{array}{l}\text { Parents and students expect that all teachers have to be professionals in special fields } \\
\text { of study and be computer specialists as well. }\end{array}$ & 3.40 \\
\hline $\begin{array}{l}\text { The textbooks are not developed for computer-assisted language learning. On the } \\
\text { contrary, there are many activities based on traditional learning. }\end{array}$ & 3.63 \\
\hline $\begin{array}{l}\text { All language teachers need their own language lab, which is equipped with } \\
\text { computers, multimedia facilities, a projection TV and a big screen. }\end{array}$ & 3.68 \\
\hline Administrators should keep all computer facilities up-graded and maintained well. & 0.98 \\
\hline $\begin{array}{l}\text { As a teacher, we need to learn how computers can be used appropriately in our } \\
\text { specific EFL classrooms and how they can be integrated into the current curriculum } \\
\text { effectively. }\end{array}$ & 4.58 \\
\hline
\end{tabular}


Table 3.1. Computer-Oriented Technology Contribution to Language Learning

\begin{tabular}{cccccc}
\hline $\mathrm{N}$ & $\mathrm{M}$ & $\mathrm{SD}$ & $\mathrm{t}$ & $\mathrm{df}$ & $\mathrm{P}$ \\
\hline 40 & 3.71 & 0.32 & 13.86 & 39 & 0.001 \\
\hline
\end{tabular}

Concerning question 4 of the study, namely "Is there any difference in using technology by male and female teachers?" all the afore-mentioned statements were given to both male and female teachers. Based on the results in Table 4 and due to the variable of technology implementation in EFL classes, both male and female teachers had positive and meaningful attitudes. They thought that technology helps students to learn and integrate different language skills, develop more interactive ways in teaching and learning languages, and understand academic subjects better. The results demonstrated that both groups' attitude toward technology implementation in EFL classes was higher than mean (3) and it was significant at the level of significance $0.05(\mathrm{P}>0.05)$. (Table 4)

Table 4. Total Attitudes of Male and Female Teachers toward Technology Implementation

\begin{tabular}{ccccccc}
\hline groups & $\mathrm{N}$ & $\mathrm{M}$ & $\mathrm{SD}$ & $\mathrm{t}$ & $\mathrm{df}$ & $\mathrm{P}$ \\
\hline male & 18 & 3.97 & 0.28 & 1.27 & 38 & 0.21 \\
female & 22 & 3.89 & 0.26 & & & \\
\hline
\end{tabular}

Teachers who reportedly value the integration of technology change their teaching in order to better incorporate technology approaches (Cox et al., 1999). Software availability and teacher willingness to use the software can have positive effects on the teachers' attitudes towards the adoption of technology in the classroom (Sepehr \& Harris, 1995). Interactive venues and discussion boards can help teachers to learn with technology instead of merely using the technology to teach (Coniam, 2002; Ducate \& Arnold, 2006). Additionally, teachers who report a strong commitment to teaching as well as their own professional development have been found to integrate technology tools more readily (Hadley \& Sheingold, 1993; Becker et al., 1999).

Table 5. Sample t-test for comparing the mean between male and female teachers' perception toward technology integration in language learning with intervening mean (3)

\begin{tabular}{ccccccc}
\hline Groups & $\mathrm{N}$ & $\mathrm{M}$ & $\mathrm{SD}$ & $\mathrm{t}$ & $\mathrm{df}$ & $\mathrm{P}$ \\
\hline Male & 18 & 4.35 & 0.40 & 0.47 & 38 & 0.63 \\
Female & 22 & 4.29 & 0.38 & & & \\
\hline
\end{tabular}

Table 6. Sample t-test for comparing the mean between male and female teachers' perception toward technology integration in language learning with intervening mean (3)

\begin{tabular}{ccccccc}
\hline Groups & $\mathrm{N}$ & $\mathrm{M}$ & $\mathrm{SD}$ & $\mathrm{t}$ & $\mathrm{df}$ & $\mathrm{P}$ \\
\hline Male & 18 & 4.05 & 0.41 & 1.20 & 38 & 0.24 \\
Female & 22 & 3.88 & 0.48 & & & \\
\hline
\end{tabular}

Table 7. Sample t-test for comparing the mean between male and female teachers' perception toward technology integration in language learning with intervening mean (3)

\begin{tabular}{ccccccc}
\hline Groups & $\mathrm{N}$ & $\mathrm{M}$ & $\mathrm{SD}$ & $\mathrm{t}$ & $\mathrm{df}$ & $\mathrm{P}$ \\
\hline Male & 18 & 3.76 & 0.34 & 0.89 & 38 & 0.39 \\
Female & 22 & 3.67 & 0.31 & & & \\
\hline
\end{tabular}

Gender differences in teachers' attitude towards using technology in language learning environment are almost absent in the present study. Concerning gender differences in teachers' attitude towards computer, Shapkaa \& Ferrarib, (2003) displayed some differences while others like Gressard and Loyd (1986), Woodrow (1992) did not display any significant gender differences. However, results of other studies showed that female teachers manifested higher levels of anxiety in their attitude towards computers more than male teachers (Sadik, 2005; Samak, 2006).

Regarding research question 5, "What is teachers' attitude toward technology implementation in EFL classes?" the results, as shown in Table 8, demonstrate that that both groups had a positive attitude toward technology implementation in EFL classes and recognized the benefits of using computer in the language classroom. Technology implementation in EFL classes was higher than mean (3) and it was significant at the level of significance $0.001(\mathrm{P}<0.001)$. (Table 8)

Table 8. Technology implementation in EFL classes

\begin{tabular}{cccccc}
\hline $\mathrm{N}$ & $\mathrm{M}$ & $\mathrm{SD}$ & $\mathrm{t}$ & $\mathrm{df}$ & $\mathrm{P}$ \\
\hline 40 & 3.92 & 0.27 & 21.14 & 39 & 0.001 \\
\hline
\end{tabular}




\subsection{Interview Data}

Students all over the world are becoming more technologically savvy. Teachers and parents have caught on to the students' increased awareness and interest in technology and have turned to technology for more educational instruction, subsequently increasing the demand for computers, video projectors, audio players, and other forms of instructional equipment in classrooms. Teachers accepted the use of technology as an undeniable part of instruction. Thus, integrating technology into language classrooms is inevitable. Most teachers stated that computer technologies could positively contribute to the quality of teaching, mode of presentation, authentic contexts, learners' motivation and cross-cultural awareness. However, it is important to recognize that computers are not a substitute for effective teaching. Computers are a tool - they are simply one type of supplement to the regular curriculum in teaching English language learners as they develop their English language skills.

Both male and female teachers used different types of technology implementations in their classes including computers, visual projectors and lab. They thought that technology facilitates learning and teaching, increases students' participation and provides visual support for students. They described the effectiveness of technology implementation and agreed that a learner-centered environment could be improved by using computers. They believed that computeroriented technology was an effective way of teaching a foreign language as it encouraged students to be active in their learning. In a traditional teacher-centered lesson, a teacher is a source of knowledge, thus the lesson is likely to be boring because the students just listen to their teachers. However, the teacher's role is quite different in a computeroriented learning environment. He/she directs and coordinates students' activities and help them organize and complete tasks. Taken together, they preferred computer-assisted language learning in EFL classes. To them this type of technology is more suitable in Iran's EFL classes. Since the students and class will be under teacher control.

All teachers pointed out benefits of using technology, in particular computer, for language teaching process. They believed that students provided with real and authentic language materials and resources might develop their language skills and become more interested in learning materials. Some teachers referred to students' induced motivation as a benefit of computer-assisted instruction. They commented that the use of technology resulted in more interesting class and increased students' class participation.

The use of technology in foreign language learning also appears to influence the development of communicative skills. In fact, computers can offer foreign language learners more than drills; "they can be a medium of real communication in the target language, including composing and exchanging messages with other students in the classroom or around the world" (Oxford, 1990, p. 79). They discussed that using technology may save class time, minimize teachers' efforts, attract students' attention and make learning interesting.

On the other hand, teachers discussed that there were some barriers to teacher's uses of technology in EFL classes including inadequate teacher training; a lack of vision of technology's potential for improving teaching and learning; a lack of time to experiment; and inadequate technical support. Time and access are the two major factors which will determine whether a teacher will plan for and use technology in their classroom lessons. The majority of responses, descriptions, and information collected usually had a reference to either time or access or both. These findings are consistent with findings from existing research which identifies time and access as critical factors in determining whether teachers use technology in their instruction or not (Chin \& Hortin, 1993; Denk, Martin \& Sarangarm, 1993; Schrum, 1995; Wang \& Chan, 1995). It seemed important to me to break these issues down farther to try and understand why these issues dominated the responses from the teachers.

Stallard (1998) states that teachers are reluctant to embrace technology because of its potential to shorten learning time for students. Stallard contends that teachers face a number of potential interruptions during the typical hour-long class and that, consequently, the actual time spent teaching and learning is shortened significantly. Hence, if the implementation of computer technology involves a "potential interruption" to teaching and learning time, teachers may avoid using the technology. Since time is short to begin with, many teachers are reluctant to "fiddle" with any type of instructional technology if it is going to reduce learning time. Time, money, and training "were identified as key barriers and constraints that keep faculty and staff from adopting technology as useful tools" (Diem et al., 2009).

The barriers inhibiting the practice of Computer-assisted Language Learning can be classified in the following common categories (a) financial barriers, (b) availability of computer hardware and software, (c) technical and theoretical knowledge, and (d) acceptance of the technology. Lidtke (cited in Madden, 1989) attribute the reluctance of teachers to embrace computer technology to a number of factors that include: anxiety from dealing with equipment, a sense of loss of control over the teaching situation, hardware and software availability, lack of technical support, time and effort for training, remaining current in the field, and appropriately implementing the technology in the classroom.

Teachers' responses indicated that different factors affect technology implementation in the classroom. They took teachers' lack of computer knowledge and skills as an influential factor into consideration. If a teacher does not know how to use computer well in the classroom, he/she feels stress and uncomfortable in from of the class.

Some teachers mentioned a lack of facilities as another inhibiting factor. They complained that insufficient facilities discourage them from using technology. Most computers are working slowly and need to be updated. Furthermore, they mentioned that there were some other concerns about using technology such as unexpected technological problems, instructional management problems, software and hardware out-of-date problems.

Despite the disadvantages that come with incorporating technology into ESL/EFL classrooms, it is essential to have technology present. No longer are classrooms traditional in the sense that a student's primary tools for success are the 
teacher, a notebook, and a pencil. Rather, classrooms are equipped or being equipped to deal with the increasing demand of more resources from which an ESL/EFL student may acquire a second or foreign language. Given the phenomenal leap that technology has made in terms of availability, accessibility, affordability, and abundance in the past decade, and considering the speed in which the expansion of the English language has occurred since the nineteen fifties, it is true to argue that the desire to learn English will not relent anytime soon. Therefore, educators and institutions that teach English to ELLs must adapt to the changes and demands of their clients by providing a wider variety of English language instruction and accessibility; all of which can be done through technology.

\section{Conclusion}

Technology in education is neither a novelty nor is it a fad. It is a part of the modern world, and is becoming more and more ubiquitous in our lives every year. It is also a proven method for improving learning. Overall, high technology use improves results in language classrooms. However, the teachers agree that using computers in the classroom cannot completely ensure better quality of education. They tend to think that the quality of education depends exclusively on the quality of teachers, not the use of technologies, and think that their positive attitude and continuous attempt to introduce new technologies and teaching materials to the class guarantee effective language instruction. This confirms that the roles of teachers are critical in structuring the learning process, organizing activities and evaluating materials in the CALL classroom, as emphasized by many researchers.

Most teachers perceive that teachers' readiness or enthusiasm for technology implementation helps students improve language skills. They consider computer-assisted classrooms as learner-oriented learning environments where students' self-directed and independent learning increases. In the new environments, students can be at the centre of learning they are responsible for their work, manage their learning by gathering information and control the pace of learning. The teachers in this study are aware of their new roles as activity guides or facilitators, not all-powerful judges for the learning process.

On the other hand, other teachers have a different point of view on teachers' roles in the computer-assisted language learning classroom. It appears that those teachers' actual reactions to the new roles of teachers in learner-centered environments created by the use of computers are not encouraging. They tend to believe that they should play dominant roles and take a responsibility for controlling students' progress and activities. It is assumed that these teachers might not have sufficient theoretical and practical knowledge of computer-assisted language learning although they generally accept the benefits of it. Also, the expectation that teachers should be experts in the use of computers is not fully supported by the teachers, although they seem to be convinced that technology implementation makes language learning interesting.

Since language is a dynamic process, the interactive environment supported by computer technology is an authentic learning tool. Finally, this approach changes the teacher's role from the central source of authority to an informed guide as each student takes more responsibility for problem-solving and learning. A better understanding of the process that teachers go through to incorporate technology into their teaching will benefit not only other teachers, but also the students who will be learning in those classrooms.

\section{References}

Almekhlafi, A. (2006). The effect of Computer-Assisted Language Learning (CALL) on United Arab Emirates EFL school students' achievement and attitude. Journal of Interactive Learning Research, 17(2), 121-142.

Atkins, N. E., \& Vasu, E. S. (2000). Measuring knowledge of technology usage and stages of concern about computing: A study of middle school teachers. Journal of Technology and Teacher Education, 8(4). 279-302.

Becker, H., Ravitz, J., \& Wong, Y. (1999). Teacher and teacher-directed student use of computers and software. Teaching, Learning, and Computing: 1998 National Survey. Report \#3.

Bancheri, S. (2006). A language teacher's perspective on effective courseware. In Randall PD and Margaret AH (Eds). Changing Language Education through CALL, (pp.31-47). New York: Routledge.

Bax, S. (2003). CALL-past, present and future. System, 31, 13-28.

Biggs, J. B. (1999). Teaching for quality learning at university: what the student does.Buckingham, UK: Open University Press.

Brown, H. D. (1991). TESOL at twenty-five: What are the issues? TESOL Quarterly, 25, 245-260.

Carr-Chellman, A. A., \& Dyer, D. (2000). The pain and the ecstasy: Pre-service teacher perceptions on changing teacher roles and technology. Educational Technology and Society, 3(2).

ChanLin, L., Hong, J., Horng, J., Chang, S., \& Chu, C. (2006). Factors influencing technology integration in teaching: A Taiwanese perspective. Innovations in Education and Teaching International, 43(1), 57-68.

Chin, S. \& Hortin, J. (1993). Teachers' perceptions of instructional technology and staff development. Journal of Educational Technology Systems, 22 (2), 83-98.

Coniam, D. (2002). Perceptions of a multimedia syllabus - making the demands of a performance test more accessible. System, 31, 55-70. 
Cope, C. J. (2000). Educationally critical aspects of the experience of learning about the concept of an information system. Unpublished dissertation, La Trobe Univ., Australia, http://ironbark.bendigo.latrobe.edu.au/staff/cope/Chris.Cope.html.

Ducate, L., \& Arnold, N. (2006). Calling on CALL: From theory and research to new directions in foreign language teaching. San Marcos, TX: Computer Assisted Language Instruction Consortium.

Gobbo, C., \& Girardi, M. (2001). Teachers"e beliefs and integration of information and communications technology in Italian schools. Journal of Information Technology for Teacher Education, 10 (1 \& 2), 63-86.

Cox, M., Webb, M., Abbott, C., Blakeley, B., Beauchamp, T., \& Rhodes, V. (1999). ICT and pedagogy: A review of the literature. British Educational Communications and Technology Agency, Department for Education and Skills.

Crystal, D. (2005). English as a global language. United Kingdom: Cambridge.

Denk, J., Martin, J., \& Sarangarm, S. (1993). Not yet comfortable in the classroom: A study of academic computing at three land-grant universities. Journal of Educational Technology Systems, 22 (1), 39-55.

Diem, K., Gamble, K., Hino, J., Martin, D., \& Meisenbach, T. (2009). Assessing county Extension programs' readiness to adopt technology; An OSU case study of two Oregon counties. Oregon: Author.

Egbert, J.L., Paulus, T. M., \& Nakamichi, Y. (2002). The impact of CALL instruction on classroom computer use: A foundation for rethinking technology in teacher education. Language Learning \& Technology, 6, 108-126. Retrieved May 17, 2008, from http://llt.msu.edu/vol6num3/egbert/

Gressard, C. P. \& Loyd, B. H. (1986). Validation studies of a new computer attitude scale. Association for Educational Data Systems Journal, 18(4), 295-301.

Hadley, M., \& Sheingold, K. (1993). Commonalities and distinctive patterns in teacherse integration of computers. American Journal of Education, 101, 261-315.

Honey, M., Culp, K. M., \& Carrigg, F. (2000). Perspectives on technology and education research: lessons from the past and present. Journal of Educational Computing Research, 23(1), 5-14.

Hurwitz, C. L. (1999). A teacher's perspective on technology in the classroom: Computer visualization, concept maps and learning logs. Journal of Education, 181, 123. Available from EBSCOhost.

Jeong, K.-O. (2006). Promoting communicative language teaching in EFL context: An English writing course mediated through the Web. English Language Teaching, 18(3), 47-68.

Johnson, E. M. (2002). The role of computer-supported discussion for language teacher education: What do the students say? CALICO Journal, 20(1), 59-79.

Jung, Y. S. (2001). Toward an effective EFL teacher development program focusing on multimedia and the Internet. English Teaching, 56(4), 141-162.

Lam,Y. (2000). Technophiliacs, technophobia: A preliminary look at why second-language teachers do or do not use technology in their classrooms. Canadian Modem Language Review, 56(3), 389-420.

Lam, Y., \& Lawrence, G. (2002). Teacher-student role redefinition during a computer-based second language project: Are computers catalysts for empowering change? Computer Assisted Language Learning, 15(3), 295-315.

Lee, S., \& Son, J.-M. (2006). The use of ICT in Korean middle school English classrooms: Practices and challenges. English Language Teaching, 18(1), 49-73.

Liu, Y., Theodore, P., \& Lavelle, E. (2004). Experimental effects of online instruction on teachers' concerns about technology integration. International Journal of Instructional Technology and Distance Learning, 1(1), Retrieved October 17, 2008, from http://www.itdl.org/journal/Jan_04/article03.htm

Loveless, A. (1999). Perception versus use: Technology in education. Convergence, 5(4), 126-128. Retrieved from http://con.sagepub.com/content/5/4/126.citation

Lyle, K. E. (2009). Teacher perceptions of their technology education curricula. (Doctoral dissertation). Retrieved from http://gradworks.umi.com/33/85/3385448.html. (UMI Number: 3385448).

Kim, H. (2002). Teachers as a barrier to technology-integrated language teaching. English Teaching, 57(2), 35-64.

Marra, R. M., \& Carr-Chellman, A. A. (1999). Undergraduate education students' perspectives on classroom technologies: A qualitative analysis. Journal of Educational Computing Research, 21(3), 282-303.

Marton, F., \& Booth, S. (1997). Learning and Awareness. Mahwah, NJ: Lawrence Erlbaum.

Marton, F., \& Säljö, R. (1976). On qualitative differences in learning. I. Outcome and process. British Journal of Educational Psychology, 46, 4-11.

Mitchell, J., \& Bluer, R. (1997). A Planning Model for Innovation: New Learning Technologies. Report of the Office of Post Compulsory Education, Training and Employment, State Training Board, Victoria, Australia, http://www.otfe.vic.gov.au/planning/model/

Oh, E., \& French, R. (2007) Pre-service teachers' perceptions of an introductory instructional technology course. CALICO Journal, 24(2), 253-267. 
Parr, J. M. (1999). Going to school the technological way: Co-constructed classrooms and student perceptions of learning with technology. Journal of Educational Computing Research, 20(4), 365-377.

Prosser, M., \& Millar, R. (1989). The how and what of learning physics. European Journal of Psychology in Education, 4, 513-528.

Prosser, M., \& Trigwell, K. (1999). Understanding learning and teaching: the experience in higher education. Philadelphia, PA: Society for Research into Higher Education \& Open University Press.

Rakes, G. C., \& Casey, H. B. (2000). An analysis of teacher concerns toward instructional technology. Retrieved May 17, 2008, from http://www.ed.uiuc.edu/IJET/v3n1/rakes/index.html

Ramsden, P. (1988). Studying learning: Improving teaching. In P. Ramsden (Ed.), Improvinglearning. New Perspectives (pp. 13-31). London: Kogan Page.

Redmond, P., Albion, P. R., \& Maroulis, J. (2005, March). Intentions and Reality: Pre-service teachers' ICT Integration during Professional Experience. Paper presented at the 16th International Conference of the Society for Information Technology \& Teacher Education (SITE 2005), Phoenix, USA.

Sadik, A. (2005). Factors influencing teachers' attitudes towards personal use and schools use of computers: New evidence from a developing nation. Evaluation Review, 2(1), 1-29.

Samak, Z. A. (2006). An exploration of Jordanian English language teachers' attitudes, skills, and access as indicator of information and communication technology integration in Jordan (Unpublished doctoral thesis). Tallahassee: Florida State University.

Schrum, L. (1999). Technology professional development. Educational Technology Research and Development, 47(4), 83-90.

Sepehr, H., \& Harris, D. (1995). Teachers"e use of software for pupils with specific learning difficulties. Journal of Computer Assisted Learning, 11, 64-71.

Shin, H.-J., \& Son, J.-B. (2007). EFL teachers' perceptions and perspectives on Internet-assisted language teaching. CALL-EJ Online, 8(2). Retrieved July 17, 2008, from http://www.tell.is.ritsumei.ac.jp/callejonline/journal/8-2/h-js jbs.html

Shapkaa, J. and Ferrarib, M. (2003) Computer-related attitudes and actions teacher candidates. Computers in Human Behavior, 20(3), 319-334.

Smerdon, B., Cronen, S., Lanahan, L., Anderson, J., Iannoti, N., \& Angeles, J. (2000). Teachers' Tools for the $21^{\text {st }}$ Century: A Report on teachers' Use of Technology. National Center for Education Statistics (NCEs) Publication \#2000102). Publication retrieved May 24, 2004 from http://nces.ed.gov/pubsearch/pubsinfo.asp?pubid=2000102.

Son, J.-B. (2002). Computers, learners and teachers: Teamwork in the CALL classroom. English Language Teaching, 14(2), 239-252.

Stallard, C. (1998) . Factors that influence the integration of technology into the secondary curriculum. [On-line]. Available: http://ed.info.apple.com/education/techlearn/adapt/adaptfactors.html.

Suh, S. (2004). Technology training and English language teacher education in Korea. Proceedings of CLaSIC 2004, Singapore, 1040-1048.

Trigwell, K., Prosser, M., \& Waterhouse, F. (1999). Relations between teachers' approaches to teaching and students' approaches to learning. Higher Education, 37, 57-70.

Wang, P. \& Chan, P. (1995). Advantages, disadvantages, facilitators, and inhibitors of computer-aided instruction in Singapore's secondary schools. Computers and Education, 25 (3), 151-162.

Woodrow, J. (1992). The influence of programming training on the computer literacy and attitudes of pre-service teachers. Journal of Research on Computing in Education, 25(2), 200-218.

Yang, S., \& Huang, Y. (2008). A study of high school English teachers" behavior, concerns and beliefs in integrating information technology into English instruction. Computers and Human Behavior, 24(3), 1085-1103.

Yildirim, S. (2000). Effects of an educational computing course on pre-service and in-service teachers: A discussion and analysis of attitudes and use. Journal of Research on Computing in Education, 32 (4), 479-495. 